\title{
HOST RANGE AND BIOLOGY OF AMRASCA BIGUTTULA BIGUTTULA
}

\section{(HEMIPTERA: CICADELLIDAE)}

\section{ANITA SINGH ${ }^{1}$, JARMANJEET SINGH ${ }^{2}$, KHUSHWINDER SINGH ${ }^{3}$ \& POONAM RANI ${ }^{4}$ \\ ${ }^{1,2,3}$ Department of Entomology, University College of Agriculture, Guru Kashi University,}

Talwandi Sabo, District Bathinda, Punjab, India

${ }^{4}$ Department of Plant Pathology, University College of Agriculture, Guru Kashi University,

Talwandi Sabo, District Bathinda, Punjab, India

\begin{abstract}
The present investigation was carried out during 2015-2017. Total 17 host plant species belong to 8 different families were recorded of okra jassid at Talwandi Sabo. This pest was noticed first time feeding mainly on green leaves of okra crops in Talwandi Sabo (Bathinda), Punjab. The biology studies revealed that the life cycle of cotton jassid passed through three different stages i.e. egg, nymph, and adult. The nymph passed through five instars and the average duration (days) of each instar was found to be $2.06 \pm 0.7,3.53 \pm 1.0,3.67 \pm 1.1,4.40 \pm 1.1$ and $4.73 \pm 1.0$ days, respectively on okra crop. The adult longevity of male and female cotton jassid was observed to be $15.80 \pm 1.6,18.66 \pm 1.8$ days, respectively on okra crop.

KEYWORDS: Amrasca Biguttula Biguttula, Okra, Host range \& Biology
\end{abstract}

Received: Feb 12, 2018; Accepted: Mar 05, 2018; Published: Apr 03, 2018; Paper Id.: IJEEFUSAPR20183

\section{INTRODUCTION}

Okra (Abelmoschus esculentus L.) annual summer vegetable crop is grown commercially throughout the tropical and sub-tropical regions of the world (Kochhar, 1986). It consists of dietary fiber, carbohydrates, protein, vitamin A, vitamin B, vitamin C and minerals (iodine, magnesium, and potassium) (Farinde, et. al., 2007; Dilruba, et. al., 2009; Saifullah \& Rabbani, 2009). It has many medicinal properties and used for treating renal colic, leucorrhoea, chronic dysentery and general weakness (Singh \& Singh, 2000). Despite its many medicinal uses, Okra is infested by many sucking insect pests (Singh, et. al., 1993; Kakar \& Dobra, 1988; Dhandapani, et. al., 2003). Earlier 72 species of insects were reported on okra out of these okra jassids was considered as the major pest (Maqsood, et. al., 2017). Okra jassid (Amrasca biguttula biguttula) belongs to family Cicadellidae and order Hemiptera. The adults are elongate and wedge-shaped with a pale green body. Its forewings have black spots on each of the apical margin and two black spots on the vertex of the head. The adults are very active with sideway movements, but quick to hopping (Jayarao, et. al., 2015). The nymphs and adults both suck plant sap and introduce salivary toxins that impair photosynthesis (Hormechan, et. al., 2001). In view of the above facts, the present studies on Host Range and Biology of Amrasca biguttula biguttula (Hemiptera: Cicadellidae) were carried out.

\section{MATERIALS AND METHODS}

Host range of cotton jassid was studied by making collections with aspirator from different plants at Talwandi Sabo. Assessment of infestation by A. biguttula biguttula on various crops was done as per the scale is 
given below:

1 Grade: 0-2 jassid per leaf

2 Grade: 3-5 jassid per leaf

3 Grade: 6-8 jassid per leaf

4 Grade: >8 jassid per leaf

Colonies were raised using okra seedling grown in pots the colonies were raised confined the jassids on the potted plants. Adult male and female population of A. biguttula biguttula were released on the potted plants for egg laying. The neonate populations were used in different studies later on.

A large number of male and female were released on the potted plants for $24 \mathrm{hr}$. They were removed the next day morning and the plants were covered with the glass chimney. The plants were observed daily for the emergence of the nymph. The period between the egg laying and first hatching was taken on the incubation periods of eggs. The eggs were laid singly within the tissues. They were observed after dissecting the plant's tissue under the dissecting microscope.

In order to study the number and the duration of the nymphal instars, 15 neonate nymphs were released singly on leaves of okra, with only cotylendonary leaf, and under in plastic containers $(4.0 \times 3.0 \mathrm{~cm})$ which were duly numbered (Brar, 1976). Daily observations were made to note the change of the instar and to remove the exuviae if any. The exuviae were removed with a moist camel-hair brush at the time of the observations. The interval between two moultings was taken as the duration of the nymphal instar and the total nymphal instar and the total nymphal period was taken as the interval between the time of the release of a neonate nymph and the emergence of the adult. The survival percentage of nymphs during different months and sex ratio of the adults reared from the nymphs in the laboratory were also worked out.

15 newly emerged adults were confined each on a separate okra, covered with the muslin cloth. Daily observations were made. The interval from the date of emergence of adult (male or female) to its death indicated the longevity.

The data were analyzed statistically and the mean and standard deviation were calculated using Microsoft Excel 2013.

\section{RESULTS AND DISCUSSIONS}

The result revealed that total 17 host plant species belong to 8 different families were recorded at Talwandi Sabo. It was found that the A. biguttula biguttula is polyphagous and caused severe damage to many host plants (Table 1). This wide host range makes the A. biguttula biguttula polyphagous. A. biguttula biguttula is polyphagous pest which found throughout the year on cotton, brinjal and China rose but it migrates to various crops for their survival and causes considerable damage to various economically important crops (Faleiro \& Rai, 1985).

Amrasca biguttula biguttla shown maximum infestation on host plants, okra (Abelmaschus esculentus), cotton (Gossypium hirsutum) and brinjal (Solanum melongena) (Table 1). 
Table 1: Host Plants of A. Biguttula Biguttla (Ishida) with its Infestation Level at Talwandi Sabo

\begin{tabular}{|l|l|l|l|c|}
\hline \multirow{4}{*}{ Host category } & \multicolumn{1}{|c|}{ Botanical Name } & Common Name & \multicolumn{1}{|c|}{ Family } & Infestation \\
\hline \multirow{5}{*}{ Field crops } & Gossypium hirsutum & Cotton & Malvaceae & 4 grade \\
\cline { 2 - 5 } & Arachis hypogaea & Groundnut & Fabaceae & 1 grade \\
\cline { 2 - 5 } & Cajanus cajan & Pigeon pea & Fabaceae & 1 grade \\
\cline { 2 - 5 } & Glycine max & Soyabean & Fabaceae & 2 grade \\
\cline { 2 - 5 } & Sorghum bicolor & Sorghum & Poaceae & 3 grade \\
\cline { 2 - 5 } & Vigna unguiculata & Cowpea & Fabaceae & 1 grade \\
\cline { 2 - 5 } & Zea mays & Maize & Poaceae & 3 grade \\
\cline { 2 - 5 } & Vigna radiata & Mung bean & Fabaceae & 1 grade \\
\hline \multirow{5}{*}{ Vegetables } & Abelmoschus esculentus & Okra & Malvaceae & 4 grade \\
\cline { 2 - 5 } & Raphanus sativus & Radish & Brassicaceae & 1 grade \\
\cline { 2 - 5 } & Solanum lycopersicum & Tomato & Solanaceae & 2 grade \\
\cline { 2 - 5 } & Solanum melongena & Brinjal & Solanaceae & 4 grade \\
\cline { 2 - 5 } & Solanum tuberosum & Potato & Solanaceae & 2 grade \\
\hline Ornamental crops & Calendula officinalis & Marigolds & Asteraceae & 2 grade \\
\hline Fruit trees /trees & Morus nigra & Mulberry & Moraceae & 1 grade \\
\hline \multirow{2}{*}{ Weeds } & Amaranthus spp. & Amaranth & Amaranthaceae & 3 grade \\
\cline { 2 - 5 } & Chloris gayana & Rhodes grass & Poaceae & 3 grade \\
\hline
\end{tabular}

The female inserted its eggs into plant tissues such as tender petioles, twigs and succulent leaves. But they prefer to lay eggs in the leaf tissue, veins usually in the spongy parenchymatous layer between the vascular bundles and the epidermis. The freshly laid eggs were translucent, slightly oval shaped and yellow in color. The fecundity in case of a single female was ranged from 13-18 eggs with an average of $15.66 \pm 1.71$ eggs (Table 2). The incubation period of eggs varied from 3 to 7 days with an average of $5.06 \pm 1.16$ days (Table 2). The eggs were oblong and tapered slightly towards the anterior end.

Leafhopper females deposit eggs inside leaf veins (Agarwal, et. al., 1978; Singh \& Agarwal, 1988). Eggs are laid singly within or near the major leaf veins in the parenchymatous layer between the vascular bundles and epidermis. The nymph and adults suck the cell sap from the ventral surface of leaves and also inject their saliva into the tissues causing toxemia. The affected leaves first become pale green, then yellow, radish and finally brick red or brown in color. This change is accompanied by curling and the leaves gradually dry away. The plants become stunted in growth and bear less number of buds and flowers; thereby the yield is adversely affected (Butani \& Jotwani, 1983).

The nymphs of A. biguttula biguttula emerged and passed through five nymphal instars. The newly emerged nymphs were transparent and yellowish in color. The description of the five instars is given below:

The duration of first instar nymphal stage ranged from 1-3 days with an average of $2.06 \pm 0.79$ days (Table 2). The nymphs were creamy-whitish color. Head was rounded in front. The eyes were blackish-brown in color and the antennae were setaceous. The wings were absent. Second instar nymph lasted for 2-5 days with a mean of $3.53 \pm 1.06$ days (Table 2). The second instar nymphs were having dull rudimentary wing pads along the posterior margin of sides of meso and metathorax. The antennae were setaceous and longer than those of the first instar. The nymphs measured 1.05 to 1.10 $\mathrm{mm}$ in length with an average of $1.07 \mathrm{~mm}$. The third instar nymphal period ranged from 2-6 days with an average of $3.67 \pm$ 1.11 days (Table 2). The nymph was yellowish green in color with prominent wing pads. The duration of the fourth instar nymph ranged from 3-6 days with a mean of $4.40 \pm 1.12$ days (Table 2). The fourth instar nymph was yellowish green, with wing pads reaching up to fourth abdominal segment. The nymphs were quite active. The final instar nymphal period ranged from 3-6 days with an average of $4.73 \pm 1.09$ days (Table 2). The fifth instar nymph was greenish yellow in color 
with wing pads reaching up to the ninth abdominal segment. The antennae quite long setaceous.

The male and female longevity was studied during different 15 replications, each on separate okra plant. The male longevity was ranged from 13-19 days with an average of $15.80 \pm 1.61$ days. The female longevity was ranged from 17-22 days with an average of $18.66 \pm 1.88$ days (Table 2 ).

Previously, Thirumalaraju (1984) reported total 17.20 eggs laid per female on okra. The longevity of adult male varied from 12 to 17 days with a mean of $15.90 \pm 1.58$ days, while for female it ranged from 12 to 18 days with a mean of $16.38 \pm 1.83$ days. The entire lifespan of leafhopper was 19 to 35 days with an average of $27.63 \pm 4.42$ days.

Shivanna, et. al., (2009) was recorded the average developmental periods of egg, $1^{\text {st }}, 2^{\text {nd }}, 3^{\text {rd }}, 4^{\text {th }}$ and $5^{\text {th }}$, nymphal instar were $6.53 \pm 0.58,1.88 \pm 0.64,2.08 \pm 0.70,2.18 \pm 0.90,2.28 \pm 0.62$ and $3.28 \pm 0.89$ days, respectively and the total nymphal period was $11.68 \pm 3.74$ days. The fecundity varied from 17 to 24 with an average of $20.33 \pm 2.65$ eggs. The average longevity of male and female adults was $15.90 \pm 1.58$ and $16.38 \pm 1.83$ days, respectively on okra crop.

Similarly, Jayasimha, et. al., (2012) reported the incubation period of eggs average of $6.42 \pm 0.37$ days. The duration of $1^{\text {st }}$ instar nymphal stage average of $1.49 \pm 0.33$ days. $2^{\text {nd }}$ instar nymphal stage mean of $1.19 \pm 0.22$ days. $3^{\text {rd }}$ instar nymphal stage average of $1.16 \pm 0.15$ days. The duration of $4^{\text {th }}$ instar nymphal stage means of $1.60 \pm 0.39$ days. The $5^{\text {th }}$ instar nymphal stage average of $1.97 \pm 0.29$ days on okra.

Jayarao, et. al., (2015), reported data of the incubation period lasts for $6.55 \pm 0.40$ days. The duration of nymphal instars was $1^{\text {st }}(6.55$ days $), 2^{\text {nd }}(1.67$ days $), 3^{\text {rd }}(1.27$ days $), 4^{\text {th }}(1.33$ days $), 5^{\text {th }}(1.67$ days $)$ and adult $(2.10$ days $)$. The total nymphal period was $8.04 \pm 0.51$ days. The male and female had a longevity of 16 and 18 days respectively, with a total fecundity of $17.53 \pm 0.52$ per female on okra.

Table 2: Nymphal Period of Amrasca Biguttula Biguttla on Okra

\begin{tabular}{|c|c|c|c|c|c|c|c|c|c|}
\hline \multirow{2}{*}{$\begin{array}{c}\text { No. of } \\
\text { Observation }\end{array}$} & \multirow{2}{*}{$\begin{array}{l}\text { Fecundity } \\
\text { (no. of eggs) }\end{array}$} & \multirow{2}{*}{$\begin{array}{l}\text { Egg duration } \\
\text { (days) }\end{array}$} & \multicolumn{5}{|c|}{$\begin{array}{c}\text { Duration of nymphal instars of A. Biguttula Biguttula } \\
\text { (days) }\end{array}$} & \multicolumn{2}{|c|}{$\begin{array}{l}\text { Adult longevity } \\
\text { (days ) }\end{array}$} \\
\hline & & & $1^{\text {st }}$ instar & $2^{\text {nd }}$ instar & $3^{\text {rd }}$ instar & $4^{\text {th }}$ instar & $5^{\text {th }}$ instar & Male & Female \\
\hline 1 & 18 & 5 & 2 & 4 & 2 & 4 & 5 & 15 & 17 \\
\hline 2 & 17 & 4 & 3 & 4 & 4 & 6 & 5 & 15 & 19 \\
\hline 3 & 14 & 6 & 1 & 2 & 4 & 6 & 3 & 18 & 20 \\
\hline 4 & 16 & 3 & 2 & 4 & 3 & 5 & 4 & 17 & 21 \\
\hline 5 & 18 & 4 & 1 & 5 & 6 & 5 & 5 & 13 & 17 \\
\hline 6 & 16 & 4 & 2 & 5 & 5 & 6 & 6 & 17 & 22 \\
\hline 7 & 15 & 7 & 3 & 3 & 4 & 3 & 3 & 14 & 17 \\
\hline 8 & 14 & 5 & 2 & 4 & 3 & 5 & 6 & 16 & 19 \\
\hline 9 & 16 & 7 & 3 & 3 & 5 & 4 & 6 & 15 & 17 \\
\hline 10 & 13 & 6 & 2 & 2 & 4 & 5 & 5 & 17 & 22 \\
\hline 11 & 13 & 5 & 3 & 5 & 3 & 4 & 4 & 16 & 18 \\
\hline 12 & 15 & 4 & 1 & 3 & 3 & 3 & 5 & 19 & 21 \\
\hline 13 & 18 & 5 & 2 & 2 & 2 & 3 & 3 & 16 & 18 \\
\hline 14 & 17 & 6 & 3 & 4 & 4 & 4 & 6 & 14 & 17 \\
\hline 15 & 15 & 5 & 1 & 3 & 3 & 3 & 5 & 15 & 18 \\
\hline Mean \pm SD & $15.66 \pm 1.7$ & $5.06 \pm 1.1$ & $2.06 \pm 0.7$ & $3.53 \pm 1.0$ & $3.67 \pm 1.1$ & $4.40 \pm 1.1$ & $4.73 \pm 1.0$ & $15.80 \pm 1.6$ & $18.66 \pm 1.8$ \\
\hline
\end{tabular}

*Mean of 15 observations

\section{ACKNOWLEDGEMENT}

Authors are thankful to Head-professor (Entomology) Dr. J. S. Brar for identification of Jassid. Authors are also thankful to Dean, University College of Agriculture, Guru Kashi University, for providing the facility in the laboratory. 


\section{REFERENCES}

1. Agarwal, R. A., Banerjee, S. K. \& Katiyar, K. N. (1978). Resistance to insects in cotton to Amrasca devastans (Distant). Cotton Fiber Tropical, 33, 404-414.

2. Brar, J. S. (1974). Studies on the bionomics of Maize Jassid, Zygnidia manaliensis. M. Sc. (Agri.) Thesis, Punjab Agriculture University, pp. 9-19.

3. Butani, D. K. \& Jotwani, M. G. (1983). Insects as a limiting factor in vegetable production. Pesticides, 17(9), 6-8.

4. Dhandapani, N., Shelkar, U. R. \& Murugan, M. (2003). Bio-intensive Pest Management (BIPM) in major vegetable crops: an Indian perspective. Food, Agriculture and Environment, 2, 333-339.

5. Dilruba, S., Hasanuzzaman, M., Karim, R. \& Nahar, K. (2009). Yield response of Okra to different sowing time and application of growth hormones. Journal of Horticultural Science and Ornamental Plants, 1, 10-14.

6. Farinde, A. J., Owolarafe, O. K. \& Ogungbemi, O. I. (2007). An overview of production, processing, marketing and utilisation of Okra in Egbedore Local Government Area of Osun State, Nigeria. Agricultural Engineering, 4, 1-17.

7. Fuleiro, J. R. \& Rai, S. (1985). Determination of vulnerable stage of crop growth to leafhopper attack in Okra. Indian Journal of Entomology, 47(2), 238-239.

8. Suvash Chandra Bala et al.,, Efficacy of Some Insecticides against Epilachna Beetle, Epilachna Vigintioctopunctata and Jassid, Amrasca Biguttula Biguttula on Brinjal in New Alluvial Zone of West Bengal, International Journal of Agricultural Science and Research (IJASR), Volume 6, Issue 5, September - October 2016, pp. 33-38

9. Hormechan, P., Wongpiyasatid, A. \& Piyapuntawanon, S. (2001). Observation of gamma irradiated cotton populations on trend of cotton leafhopper resistance using Hopper Burn Index. Kasetsart Journal Natural Science, (35), 386- 391.

10. Jayarao, B., Abulkhader, S. B., Naik, L. K. and Vinaykumar, M. M. (2015). Assessment of biology and morphometric characteristics of different stages of leafhopper, Amrasca biguttula biguttula (Ishida) on Okra. The Bisscan, 10(2), 671-674.

11. Jayasimha, T. G., Rachana, R. R., Manjunatha, M. \& Kumar, V. B. R. (2012). Biology and Seasonal incidence of leafhopper, Amrasca biguttula biguttula (Ishida) (Hemitpera: Cicadellidae) on Okra. Pest Management in Horticultural Ecosystems, $18(2), 149-153$.

12. Kakar, K. L. \& Dobra, G. S. (1988). Insect-pests of Okra, Abelmoschus esculentus (Linn.) Monech. and their control under Mid-hill Conditions. Journal of Insect Science, 1(2), 195-198.

13. Kochar, S. L. (1986). Tropical Crops. A Text Book of Economic Botany. Macmillan Indian Limited, pp. 263-264.

14. Maqsood, A. C., Muhammad, I. K., Naeem, A. B., Fida, H. M., Sanaullah, M., Khadim, H. L, Naveed, A. C. \& Muhammad, A. R. (2017). Varietal resistance of Okra against Cotton Jassid, Amrasca biguttula biguttula (Ishida). Journal of Entomology and Zoology Studies, 5(3), 1647-1650.

15. Saifullah, M. \& Rabbani, M. G. (2009). Evaluation and characterization of Okra (Abelmoschus esculentus L. Moench.) genotypes. South Asian Association for Regional Cooperation, Journal of Agriculture, 7, 92-99.

16. Singh, D. S. \& Singh, J. P. (2000). Relative susceptibility of Spilarctia obliqua larvae against Some Pyrethroid and NonPyrethroid Insecticides. Indian Journal of Entomology, 62, 289-294.

17. Singh, J. A., Sohi, S., Dhaliwal, Z. S. \& Mann, H. S. (1993). Comparative incidence of Helicoverpa armigera Hb. and other pests on okra and sunflower intercrops in cotton under Punjab conditions. Journal of Insect Science, 6, 137-138. 
18. Singh, R. \& Agarwal, R. A. (1988). Influence of leaf-veins on ovipositional Behaviour of Jassid, Amrasca biguttula biguttula (Ishida). Journal of Cotton Research Development, 2, 41-48.

19. Shivanna, B. K., Nagaraja, D. N., Manjunatha, M., Devi, S. G., Predeep, S. \& Girijesh, G. K. (2009). Bionomics of Leafhopper, Amrasca biguttula biguttula (Ishida) on transgenic Bt-cotton, Karnataka. Journal Agriculture Science, 22(3), 538-540.

20. Thirumalaraju, G. T. (1984). Bionomics and control of Cotton Jassid, Amrasca biguttula biguttula (Ishida) (Homoptera: Cicadellidae) and screening of cotton varieties for their resistance to the Pest. M. Sc. (Agri.) Thesis, University of Agricultural Sciences, Dharwad (India). 